\title{
DAYA TOLAK INFUSA DAUN PANDAN WANGI (Pandanus amaryllifolius Roxb.) TERHADAP PELETAKAN TELUR NYAMUK AEDES SPP
}

\author{
Anggie Cahyadi ${ }^{1}$, Sri Wahdaningsih ${ }^{2 *)}$, Diana Natalia $^{1}$ \\ 1) Program Studi Pendidikan Dokter, Fakultas Kedokteran, Universitas Tanjungpura \\ Pontianak, Kalimantan Barat. \\ 2) Program Studi Farmasi, Fakultas Kedokteran, Universitas Tanjungpura Pontianak, \\ Kalimantan Barat. \\ *)Email: wahdanie@gmail.com
}

\begin{abstract}
Aedes spp larval resistance against chemical insecticide has been reported in many country. The new methods that can be used to control the mosquito populations as a dengue fever vector and alternative compound which is safe for environtment and can't cause the resistance need to be found. Pandan leaves have aromatic fragrant that can be expected as a oviposition deterrent effect against Aeses spp mosquito. To know oviposition deterrent effects and optimum consentration of pandan leaves (Pandanus amaryllifolius Roxb.) infusa against Aedes spp. This research was an experimental research using six groups of concentration. There was $0 \mathrm{~mL} / \mathrm{L}$ (control), 3 $\mathrm{mL} / \mathrm{L}, 3,5 \mathrm{~mL} / \mathrm{L}, 4 \mathrm{~mL} / \mathrm{L}, 4,5 \mathrm{~mL} / \mathrm{L}$ and $5 \mathrm{~mL} / \mathrm{L}$. Every groups would be repeated by fourth. Ovitraps with different concentration of pandan leaves infusa placed at research location. The mosquito eggs that caught at the ovitrap would be counting and identifying in the laboratorium. Data was analyzed using One Way Anova test via computer program SPSS 19.0 and then continued by LSD test with 95\% confidence level. The repellency percentage at $3 \mathrm{~mL} / \mathrm{L}$ concentration is $30.35 \%$; $3,5 \mathrm{~mL} / \mathrm{L}$ is $55.35 \%$; $4 \mathrm{~mL} / \mathrm{L}$ is $65.17 \%$; $4,5 \mathrm{~mL} / \mathrm{L}$ is $82.14 \%$ and $5 \mathrm{~mL} / \mathrm{L}$ is $100 \%$ with significancy value is $0,000(p<0,05)$.
\end{abstract}

Keywords: Oviposition deterrent effects, Pandanus amaryllifolius Roxb., oviposition, Aedes spp.

\section{PENDAHULUAN Latar Belakang}

Berbagai faktor kependudukan berpengaruh pada peningkatan dan penyebaran kasus DBD, antara lain pertumbuhan penduduk yang tinggi; urbanisasi yang tidak terencana dan tidak terkendali; tidak efektifnya kontrol vektor nyamuk yang efektif di daerah endemis dan peningkatan sarana transportasi. ${ }^{1}$

Upaya pengendalian terhadap faktor kependudukan tersebut (terutama kontrol vektor nyamuk) harus diupayakan, disamping pemberian terapi yang optimal pada penderita DBD, dengan tujuan menurunkan jumlah kasus dan kematian akibat penyakit ini. ${ }^{1}$ Bentuk pengendalian ini dapat dilakukan secara mekanik, biologi, kimia, atau perubahan sifat genetik. Pengendalian yang paling populer saat ini adalah pengendalian secara kimiawi dengan menggunakan insektisida karena bekerjanya lebih efektif dan hasilnya cepat terlihat bila dibandingkan dengan pengendalian biologis. ${ }^{2}$

Resistensi terhadap temephos dan organofosfat yang merupakan bahan aktif dari bubuk Abate telah dilaporkan dibeberapa negara, seperti Brazil, Thailand, Kuba dan Argentina. ${ }^{3-6}$ Dari penelitian Damar dan Widiarti $^{7}$ tahun 2005, dilaporkan adanya resistensi sebagian populasi nyamuk Aedes aegypti di beberapa daerah di DI Yogyakarta dan provinsi Jawa Tengah. Sedangkan dari penelitian Intan $\mathrm{dkk}^{8}$ tahun 2007 ditemukan adanya resistensi nyamuk Aedes aegypti di daerah Surabaya, Bandung dan Palembang. Resistensi terhadap beberapa jenis insektisida seperti deltamethrin, malathion, permethrin dan pyrethroid juga dilaporkan di Thailand. ${ }^{9,10}$

Perlu dicari cara baru dan bahan alternatif yang dapat dipakai untuk mengendalikan populasi nyamuk sebagai vektor penyebab penyakit demam berdarah yang aman bagi lingkungan dan tidak menimbulkan terjadinya resistensi. Tanaman pandan wangi memiliki bau khas aromatik yang diharapkan memiliki potensi terhadap penolakan peletakan telur nyamuk Aedes spp. sehingga diharapkan dapat memutus rantai perkembangbiakan atau perindukan nyamuk tersebut yang pada akhirnya dapat mengendalikan populasi vektor nyamuk penyebab penyakit DBD.

\section{METODE PENELITIAN}

Jenis penelitian ini merupakan penelitian eksperimental sederhana dengan rancangan post test only group control design. Penelitian dilakukan di Jalan Flores, Kelurahan Akcaya, Pontianak Selatan, 
dan Laboratorium Hama dan Penyakit Fakultas Pertanian Universitas Tanjungpura pada bulan Februari 2012 - April 2013.

Pada penelitian ini, subjek dibagi menjadi 2 kelompok, kelompok I disebut kelompok perlakuan dengan konsentrasi infusa yang berbeda dan kelompok II disebut kelompok kontrol. Metode yang digunakan dalam penelitian ini adalah rancang acak kelompok (RAK), yaitu penelitian dilakukan dengan menggunakan enam macam konsentrasi/dosis perlakuan, untuk setiap perlakuan masing-masing dilakukan empat kali pengulangan. Konsentrasi yang digunakan pada penelitian ini adalah $0 \mathrm{~mL} / \mathrm{L}$ (sebagai kontrol), $3 \mathrm{~mL} / \mathrm{L}, 3,5 \mathrm{~mL} / \mathrm{L}, 4 \mathrm{~mL} / \mathrm{L}, 4,5 \mathrm{~mL} / \mathrm{L}$ dan 5 $\mathrm{mL} / \mathrm{L}$. Daun pandan wangi sebanyak 100 gram dibersihkan dan dirajang sampai halus. Selanjutnya daun dimasukkan kedalam panci infus, kemudian ditambahkan akuades sebanyak $200 \mathrm{ml}$, dipanaskan selama 15 menit dihitung setelah suhu mencapai $90^{\circ} \mathrm{C}$.

Uji penolakan dilakukan dengan memasang perangkap telur nyamuk yang telah di isi infusa dengan konsentrasi perlakuan pada lokasi penelitian. Telur nyamuk yang terperangkap kemudian di identifikasi dan dihitung di laboratorium. Persentase daya tolak kemudian dihitung dengan rumus standar dari Xue ${ }^{11}$, sebagai berikut:

$$
\text { Daya Tolak }(\%)=\frac{\mathrm{C}-\mathrm{T}}{\mathrm{C}} \times 100
$$

dimana $\mathrm{C}$ adalah jumlah rata-rata telur nyamuk yang terperangkap dalam perangkap kontrol, dan $\mathrm{T}$ adalah jumlah rata-rata telur nyamuk yang terperangkap dalam perangkap dengan perlakuan.
Data diolah menggunakan uji One Way Anova melalui program komputer SPSS 19.0 dan dilanjutkan uji LSD dengan taraf kepercayaan $95 \%$.

\section{HASIL DAN PEMBAHASAN 1. Uji Pendahuluan}

Uji pendahuluan dilakukan untuk mengetahui konsentrasi perlakuan yang memiliki efek daya tolak sebanyak $50 \%$ dari jumlah telur nyamuk yang terperangkap pada kelompok kontrol. Berdasarkan hasil dari uji pendahuluan dapat dilihat persentase daya tolak untuk peletakan telur nyamuk Aedes spp. sebesar $\pm 50 \%$ dari jumlah telur nyamuk yang terdapat pada kelompok kontrol adalah pada konsentrasi $4 \mathrm{~mL} / \mathrm{L}$, ini berarti konsentrasi ini menjadi acuan untuk menentukan kisaran-kisaran interval konsentrasi yang digunakan pada uji sesungguhnya.

Hasil uji pendahuluan dari efek daya tolak infusa daun pandan wangi terhadap peletakan telur nyamuk Aedes spp. dapat dilihat pada tabel 1.

\section{Uji Sebenarnya}

Kisaran interval konsentrasi yang digunakan pada uji sebenarnya diperoleh dengan cara menaikkan atau menurunkan nilai konsentrasi acuan pada uji pendahuluan, di mana jarak interval tidak terlalu jauh. Kisaran interval konsentrasi yang digunakan pada uji sebenarnya adalah $0 \mathrm{~mL} / \mathrm{L}$ (kontrol), $3 \mathrm{~mL} / \mathrm{L}, 3,5 \mathrm{~mL} / \mathrm{L}, 4 \mathrm{~mL} / \mathrm{L}, 4,5 \mathrm{~mL} / \mathrm{L}$ dan 5 $\mathrm{mL} / \mathrm{L}$.

Hasil penelitian pada uji sebenarnya dapat dilihat pada tabel 2 .

Tabel 1. Daya Tolak Pada Uji Pendahuluan Infusa Daun Pandan Wangi Terhadap Peletakan Telur Nyamuk Aedes spp.

\begin{tabular}{cccc}
\hline Kelompok Perlakuan & Konsentrasi & Jumlah Telur & \% Daya Tolak \\
\hline Kontrol & $0 \mathrm{~mL} / \mathrm{L}$ & 27 & - \\
P1 & $2 \mathrm{~mL} / \mathrm{L}$ & 16 & $40.74 \%$ \\
P2 & $4 \mathrm{~mL} / \mathrm{L}$ & 13 & $51.85 \%$ \\
P3 & $6 \mathrm{~mL} / \mathrm{L}$ & 0 & $100 \%$ \\
P4 & $8 \mathrm{~mL} / \mathrm{L}$ & 0 & $100 \%$ \\
P5 & $10 \mathrm{~mL} / \mathrm{L}$ & 0 & $100 \%$
\end{tabular}

(Sumber: Data Primer, 2013) 
Tabel 2. Daya Tolak Pada Uji Sebenarnya Infusa Daun Pandan Wangi Terhadap Peletakan Telur Nyamuk Aedes spp.

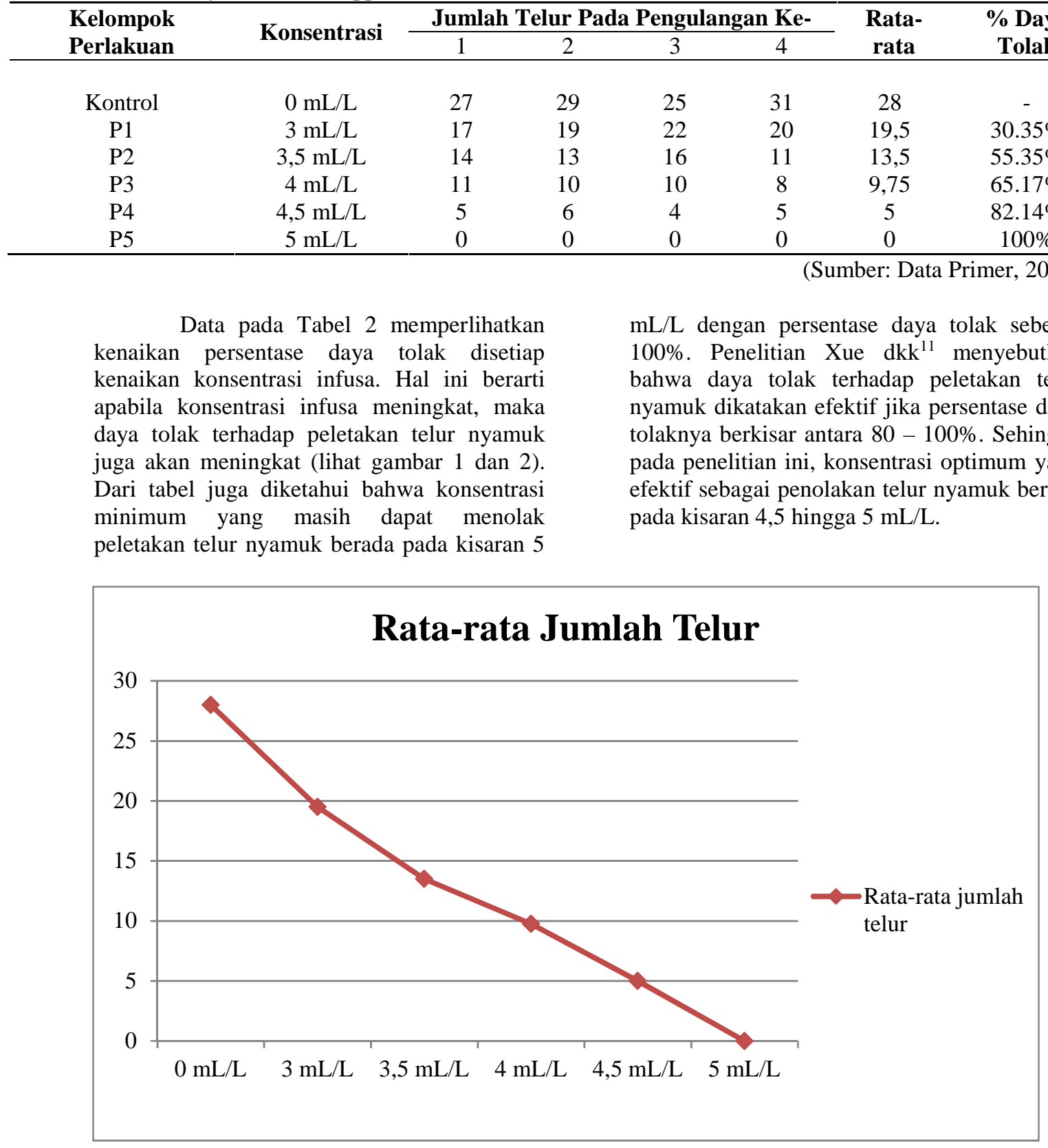

Gambar 1. Diagram garis yang menunjukkan rata-rata jumlah telur pada tiap konsentrasi infusa (Sumber: Data Primer, 2013) 
Gambar 1 menunjukkan diagram garis yang memperlihatkan rata-rata jumlah telur pada tiap konsentrasi infusa. Terjadi penurunan grafik pada setiap kenaikan konsentrasi infusa. Hal ini menunjukkan bahwa semakin tinggi konsentrasi infusa, maka rata-rata jumlah telur nyamuk akan menurun. Gambar 2 menunjukkan diagram garis yang memperlihatkan persentase daya tolak infusa pada tiap konsentrasi. Terjadi kenaikan grafik pada setiap kenaikan konsentrasi infusa. Hal ini berarti persentase daya tolak semakin meningkat seiring dengan peningkatan konsentrasi infusa.

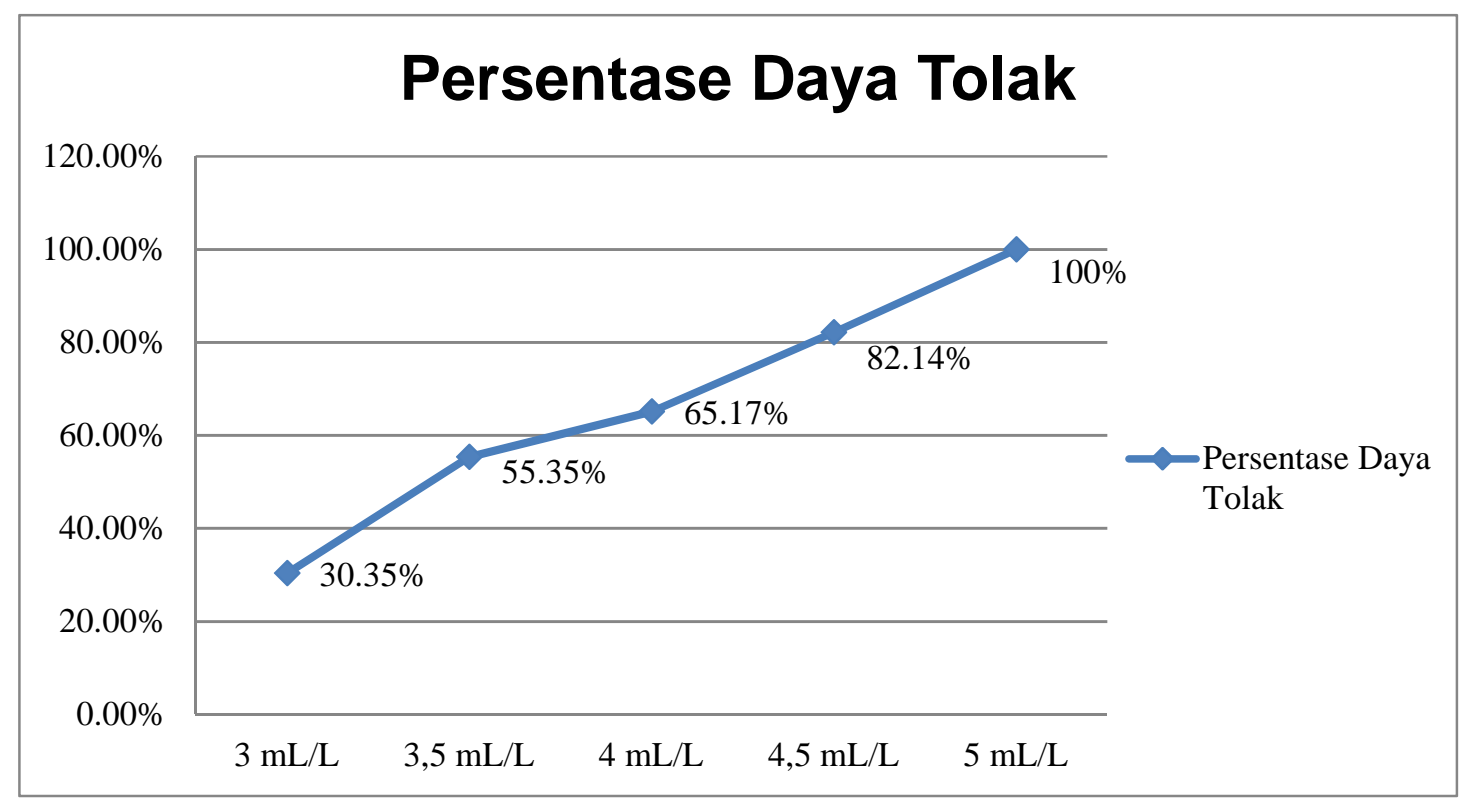

Gambar 2. Diagram garis yang menunjukkan persentase daya tolak infusa pada tiap konsentrasi (Sumber: Data Primer, 2013)

\section{Analisis Statistik}

Pada uji One-Way ANOVA, nilai significancy menunjukkan angka $0,000(\mathrm{p}<0,05)$ yang artinya paling tidak terdapat perbedaan rata-rata jumlah telur yang bermakna pada dua kelompok konsentrasi. Untuk mengetahui kelompok perlakuan mana yang terdapat perbedaan bermakna, dilakukan analisis Post-Hoc dengan menggunakan LSD. Uji Post-Hoc menunjukkan terdapat perbedaan jumlah telur yang berbeda secara bermakna pada semua kelompok perlakuan (nilai $\mathrm{p}<0,05$ dengan Indeks Kepercayaan $95 \%$ tidak tercakup angka 0 ).

\section{Preparasi Sampel dan Pembuatan Infusa}

Pada penelitian ini, bagian tumbuhan yang digunakan adalah daun. Hal ini dikarenakan zat-zat kimia dan metabolit sekunder pada tanaman ini disimpan di dalam vakuol yang terdapat di seluruh permukaan daun. ${ }^{12}$ setelah dibersihkan dikeringanginkan kemudian dirajang hingga halus. Hal ini bertujuan untuk memperbesar luas permukaan tanaman sehingga zat aktif yang dapat ditarik oleh zat penyari menjadi lebih banyak. ${ }^{14}$ Pembuatan infusa menggunakan dua buah panci yang saling bertumpuk, dimana panci yang di atas diisi bahan yang akan diekstraksi, dimana bahan pada penelitian ini adalah daun pandan dan zat penyarinya, yaitu air. Panci yang di bawah hanya diisi air, yang berkontak langsung dengan api. Ketika panci yang dibawah airnya mendidih hingga $100^{\circ} \mathrm{C}$, maka panas yang diterima oleh panci atas hanya bersuhu $90^{\circ} \mathrm{C}$ saja. Kondisi demikian ini diperlukan agar zat aktif dalam bahan tidak rusak oleh panas berlebihan. Infusa yang telah jadi kemudian didinginkan dan disaring menggunakan kain flanel. Pendinginan dilakukan karena tanaman daun pandan wangi mengandung minyak atsiri yang mudah menguap apabila disaring dalam keadaan panas.

\section{Peletakan Perangkap Telur Nyamuk dan Identifikasi Telur Nyamuk}

Perangkap telur nyamuk yang telah diberi infusa sesuai dengan konsentrasi yang digunakan kemudian diletakkan pada lokasi penelitian yang terlindung dari sinar matahari langsung. Hal ini sesuai dengan penelitian Neneng $\mathrm{dkk}^{15}$ yang menunjukkan bahwa lokasi yang paling banyak ditemukan larva dan telur nyamuk Aedes adalah tempat-tempat yang terlindung dari sinar matahari langsung. Suhu udara yang diperlukan nyamuk untuk 
meletakkan telurnya berada pada temperatur sekitar $20-30^{\circ}$ C. Berdasarkan catatan empiris dari Stasiun Meteorologi Supadio Pontianak dan Stasiun Klimatologi Siantan Kabupaten Pontianak, umumnya suhu udara di daerah Kalimantan Barat cukup normal namun bervariasi, yaitu rata-rata sekitar $25,8^{\circ} \mathrm{C}$ sampai dengan $28,3^{\circ} \mathrm{C}$. Jadi, lokasi pada penelitian ini memenuhi syarat untuk nyamuk meletakkan telurnya.Pengamatan dan pencatatan dilakukan pada 24 - 48 jam pertama setelah peletakan perangkap. Hal ini dikarenakan telur nyamuk akan menetas dalam waktu $1-2$ hari setelah peletakannya. ${ }^{16}$
Semua telur nyamuk yang terperangkap kemudian diidentifikasi di laboratorium. Identifikasi telur nyamuk dilakukan dengan menggunakan mikroskop cahaya dengan pembesaran $4 x$ hingga 10x. Identifikasi bertujuan untuk membedakan telur nyamuk Aedes dengan telur nyamuk lain atau benda asing yang bentuknya mirip dengan telur nyamuk yang dapat membuat kesalahan dalam perhitungan jumlah telur nyamuk. Pengamatan di laboratorium menunjukkan adanya telur Aedes yang khas yang berbentuk bulat lonjong, berwarna hitam dan soliter (lihat gambar 3).

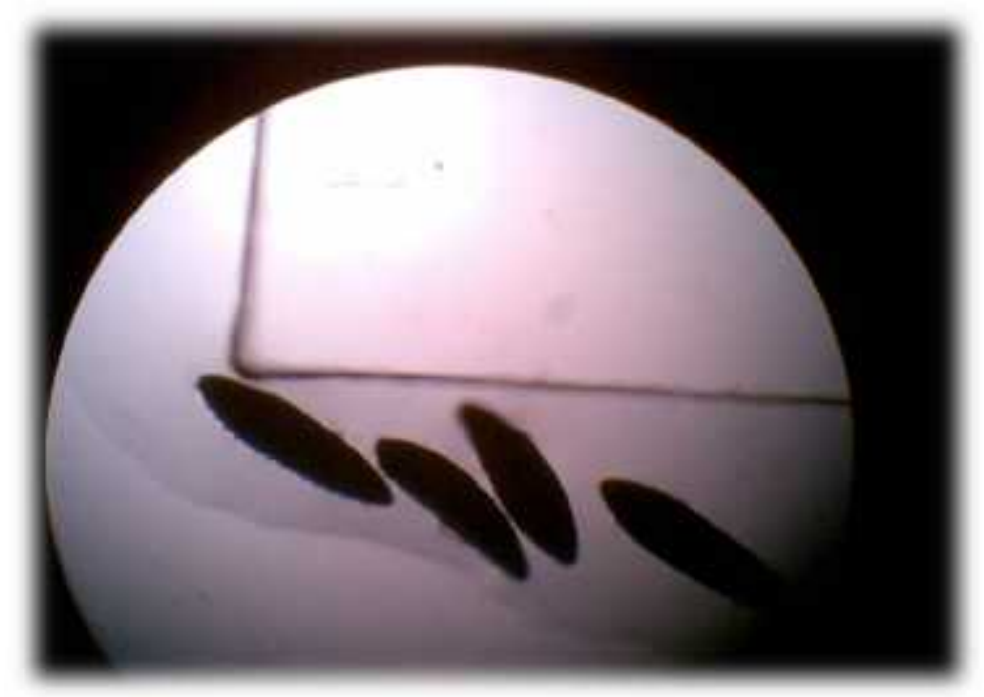

Gambar 3. Telur Aedes berbentuk bulat lonjong dan berwarna hitam (perbesaran 10x).

Hal ini berbeda dari morfologi telur nyamuk Anopheles yang mempunyai pelampung pada kedua sisinya dan nyamuk Culex yang bergerombol seperti peluru. ${ }^{17-19}$

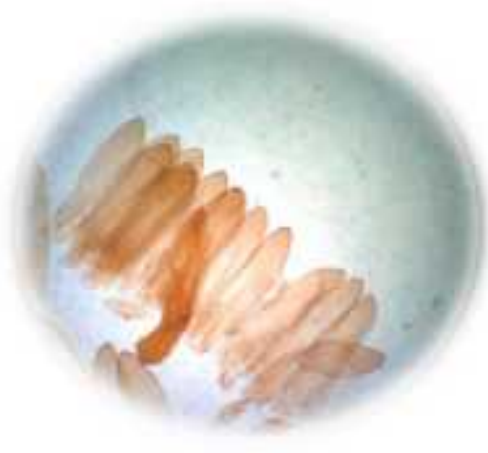

(a)

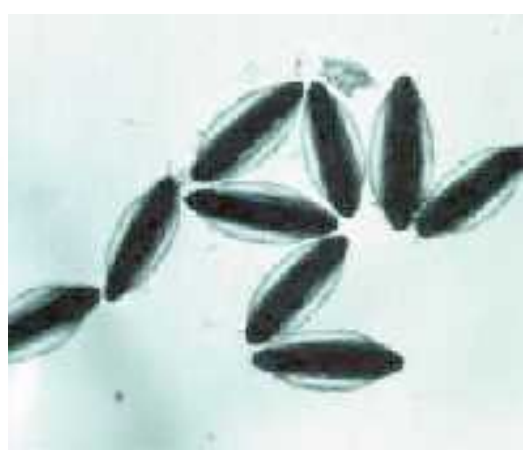

(b)

Gambar 4. (a): Telur nyamuk Culex yang bergerombol; (b): Telur nyamuk Anopheles yang memiliki pelampung pada kedua sisinya. (perbesaran 10x $)^{17,19}$ 
Efek Daya Tolak Infusa Daun Pandan Wangi Terhadap Peletakan Telur Nyamuk Aedes spp.

Daun pandan mengandung alkaloida, saponin, flavonoida, tannin, polifenol dan zat warna. ${ }^{20}$ Berdasarkan penelitian Hastuti ${ }^{21}$ diketahui bahwa saponin dan polifenol dapat menghambat bahkan membunuh larva nyamuk. Saponin dapat merusak membran sel dan mengganggu proses metabolisme serangga, sedangkan polifenol sebagai inhibitor pencernaan serangga. Apabila polifenol termakan oleh serangga, maka zat tersebut akan menurunkan kemampuan serangga dalam mencerna makanan.

Bau khas pada daun pandan disebabkan oleh kandungan minyak atsiri dan senyawa kimia yang disebut 2-acetyl pyrroline. ${ }^{22}$ Selain itu, penelitian yang dilakukan oleh Listyawati $\mathrm{dkk}^{23}$ menemukan bahwa senyawa-senyawa penyusun aroma daun pandan wangi segar (berdasarkan Spektra dari Spektroskopi-Massa) adalah Limonen, $\mathrm{C}_{14} \mathrm{H}_{30}$ Tetradekana dan Fenol 2,6-bis (1,1-dimetil)-4-metil. Penelitian Zaki $\mathrm{dkk}^{24}$ di Malaysia menunjukkan bahwa Limonen merupakan senyawa aromatik yang ditemukan pada kulit jeruk dan lemon yang telah terbukti efektif sebagai penolak gigitan nyamuk Aedes.

Untuk mengetahui keadaan lingkungan sekitar, nyamuk menggunakan reseptor sensoris yang terdapat di bagian tubuhnya, seperti reseptor penglihatan, pendengaran, mekanoreseptor dan kemoreseptor (reseptor kimia). ${ }^{25}$ Untuk mengetahui lokasi tempat bertelur dan mencari makan, nyamuk akan menangkap sinyal kimia yang ada di udara (airborne chemical signal) atau sinyal bau. ${ }^{26}$ Sinyal ini merupakan stimulus yang paling berpengaruh dalam pola tingkah laku nyamuk. ${ }^{27}$ Senyawasenyawa ini akan menempel pada reseptor bau (odorant receptor) yang terletak di antenadan palpi maksilaris nyamuk.

Beberapa senyawa yang telah diketahui berfungsi sebagai atraktan (penarik) dalam mencari makan (host-seeking) adalah karbondioksida $\left(\mathrm{CO}_{2}\right)$ dan asam laktat. Sedangkan produk sisa dari bakteri dan bahan organik lain yang terdapat di dalam air merupakan senyawa atraktan yang akan ditangkap oleh reseptor dan akan dikenali sebagai tempat bertelur yang cocok. Pada nyamuk Aedes dan Anopheles, senyawa 3-methylindole dan ethyl propionate merupakan atraktan paling kuat untuk meletakkan telurnya. ${ }^{27}$

Secara umum, mekanisme penolakan (repellent) terhadap nyamuk adalah dengan mengganggu atau memblok reseptor bau ini. Contohnya DEET ( $N, N$-diethyl-3-methyl benzamide) yang merupakan penolak atau repellent sintetis yang telah digunakan secara luas, bekerja dengan memblok reseptor bau yang ada pada nyamuk. Pada nyamuk Aedes, reseptor yang diblok adalah reseptor OR83b. Hal ini akan menurunkan ambang sensitivitas reseptor bau tersebut terhadap stimulus dari senyawa atraktan yang lain. ${ }^{28-30}$

Senyawa aromatik yang terdapat pada beberapa tanaman juga bekerja dengan cara memblok reseptor OR83b, seperti citronella dan geraniol pada tanaman sereh wangi (Cymbophogon nardus), PMD (para-methane 3-8, diol) dan limonen pada kulit buah lemon (Corymbia citriodora). ${ }^{28}$ Senyawa aromatik utama pada tanaman pandan wangi adalah 2-acetyl pyrroline dan limonen. Senyawa-senyawa inilah yang kemungkinan berperan dalam penolakan peletakan telur nyamuk.

\section{KESIMPULAN}

Infusa daun tanaman pandan wangi (Pandanus amaryllifolius Roxb.) memiliki daya tolak terhadap peletakan telur nyamuk Aedes spp. Konsentrasi optimum yang efektif sebagai penolakan telur nyamuk berada pada kisaran 4,5 hingga $5 \mathrm{~mL} / \mathrm{L}$.

\section{DAFTAR PUSTAKA}

1. Chen K, Pohan HT, Sinto R. Diagnosis dan Terapi Cairan pada Demam Berdarah Dengue. Medicinus. 2009;1(22):3-7.

2. Susanna D, Rahman A, Pawenang ET. Potensi Daun Pandan Wangi Untuk Membunuh Larva Nyamuk Aedes aegypti. Jurnal Ekologi Kesehatan. 2003;2(2):228-31.

3. Jose BPL, Marcella PDaC, Ronaldo CDaSJ, Allan KRG, Sidinei DaSS, Ima AB, dkk. Resistance of Aedes aegypti to organophosphate in Several Municipalities in the State of Rio De Jeneiro and Espirito Santo, Brazil. American Journal of Tropical Medicine and Hygiene. 2003;68(3):329-33.

4. Pungasem P, Narumon K, Vanida D, Yupha R, Yuki E, Supatra T. Temephos Resistance in Two Forms of Aedes aegypti and Its Significance for The Resistance Mechanism. Southeast Asian Journal of tropical Medicine and Public Health. 2003;34(4):786-92.

5. Angela FH, Shavanti R, Hilary R. Pyrethroid Resistance in Aedes aegypti from Grand Cayman. American Journal of Tropical Medicine and Hygiene. 2010;83(2):277-84.

6. Emilia S, Alejandro L, Eduardo Z, Susana L, Hector M. Aedes aegypti Resistance to Temephos in Argentina. Journal of the American Mosquito Control Association [internet]. 2008 [diakses tanggal 13 Januari 2012] 24(4):[sekitar 1 halaman].Tersedia di: http://dx.doi.org/10.2987/5738.1 
7. Damar TB, Widiarti. Susceptibility of Dengue Haemorraghic Fever Vector (Aedes aegypti) Against Organophosphate Insecticides (Malathion and Temephos) in Some Districts of Yogyakarta and Central Java Provinces. Vector and Reservoir Control Research Unit Salatiga. 2005

8. Intan A, Sita A, Marselina T. Resistance of Aedes aegypti (Diptera: Culicidae) in 2006 to Pyrethroid Insecticides in Indonesia and Its Association with Oxidase and Esterase Levels. Pakistan Journal of Biological Sciences. 2007;10(20):3688-92.

9. Rapeeporn Y, Rachada K, Theeraphap C, Pornpimol R. Characterization of Deltamethrin Resistance in Fields Populations of Aedes aegypti in Thailand. Jounal of Vector Ecology. 2005;30(1):144-50.

10. Alongkot P, Jeffrey GS, Laura CH. Insecticide Susceptibility of Aedes aegypti and Aedes albopictus Across Thailand. Journal of Medical Entomology [internet]. 2005 [diakses tanggal 13 Januari 2012];42(5): [sekitar 1 halaman.]. Tersedia di: http://dx.doi.org/10.1603/00222585(2005)042[0821:ISOAA]2.0.CO;2

11. Tawatsin A, Asavadachanukorn P, Thavara U, Wongsinkongman P, Bansidhi J, Boonruad T dkk. Repellency of Essential Oils Extracted from Plants in Thailand Against Four Mosquito Vectors (Diptera: Cullicidae) and Oviposition Deterrent Effects Against Aedes aegypti (Diptera: Cullicidae). Southeast Asian Journal of Tropical Medicine and Public Health. 2003;37(5):915-3

12. Wakte KV, Nadaf AB, Krishnan F dan Thengane RJ. Studies on Lower Epidermal Papillae, The Site Of Storage Of Basmati Rice Aroma Compunds on Pandanus amaryllifolius Roxb. Current Sciences. 2007;93(2):238-42.

13. Tomlinson PB. A Study of Stomatal Structure in Pandanaceae. Pacific Science. 1965;19(2):38-54.

14. Departemen Kesehatan Republik Indonesia. Sediaan Galenik. Jakarta: DepKes RI; 1986.

15. Syarifah N, Rusmatini T, Djatie T, Huda F. Ovitrap Ratio of Aedes aegypti Larvae Collected Inside and Outside Houses in a Community Survey to Prevent Dengue Outbreak, Bandung, Indonesia, 2007. Prociding ASEAN Congress Tropics and Medical Parasitology. 2008;3:11620.

16. Depkes RI. Perilaku Hidup Nyamuk Aedes aegypti Sangat Penting Diketahui Dalam Melakukan Kegiatan Pemberantasan Sarang Nyamuk Termasuk Pemantauan Jentik Berkala [internet] januari 2012]. Tersedia di: http://www.depkes.go.id/downloads/Bulletin\%2 0Harian\%2010032004.pdf

17. Sutanto I, Ismid SI, Sjarifuddin PK, Sungkar S. Buku Ajar Parasitologi Kedokteran. Edisi ke-4. Jakarta: FKUI; 2008.

18. Hinton HE. Observations on The Biology and Taxonomy of The Eggs of Anopheles Mosquitos. Bulletin of Entomological Research. 1968;57:495-508.

19. Linley JR, Geary MJ dan Russel RC. The Eggs of Aedes alboannulatus and Aedes rubrithorax (Diptera: Cullicidae). Mosquito Systematics. 1991;23(2):132-43.

20. Dalimartha S. Atlas Tumbuhan Obat Indonesia. Jilid 1. Jakarta : Trubus Agriwidya; 2003.

21. Hastuti H. Daya Bunuh Ekstrak Daun Pandan Wangi (Pandanus amaryllifolius Roxb.) terhadap Larva Anopheles aconicus Donitz [Skripsi]. Fakultas Kedokteran: UNS; 2008.

22. Standard of ASEAN Herbal Medicines. Volume II. Jakarta. 2004.

23. Listyawati M, Tranggono dan Suyitno. Pembuatan Dan Karakterisasi Bubuk Pandan Wangi Siap Pakai. Agrosains. 1999;12(2):13344.

24. Zaki MZ, Ali M, Ahmad AS, Patah MF, Hassan H, Jamil IK dkk. Four Monoterpene Compounds: Repellency Evaluation Against Aedes aegypti. Malaysian Journal of Sciences. 2000;24(1):6978.

25. Bowen MF. The Sensory Physiology of HostSeeking Behaviour in Mosquitoes. Annual Reviews Entomology. 1991;36:139-58.

26. Leite NR, Krogh R, Xu W, Ishida Y, Iulek J, Leal WS dkk. Structure of an Odorant-Binding Protein from The Mosquito Aedes aegypti Suggest a Binding Pocket Covered by a $\mathrm{pH}-$ Sensitive "Lid". Plos One. 2009;4(11):1-7.

27. Takken W dan Knols BGJ. Odor-Mediated Behaviour of Afrotropical Malaria Mosquitoes. Annual Review Entomology. 1999;44:131-57.

28. Maia MF dan Moore SJ. Plant-Based Insect Repellents: a Review of Their Efficacy, Development and Testing. Malaria Journal. 2011;10:1-15.

29. Pelletier J, Hughes DT, Luetje CW dan Leal WS. An Odorant Receptor From The Southern House Mosquito Culex pipiens quinquefasciatus Sensitive to Oviposition Attractants. Plos One. 2010;5:1-8.

30. Bohbot JD dan Dickens JC. Insect Repellents: Modulators of Mosquito Odorant Receptor Activity. Plos One. 2010;5:1-11. 